\title{
Comparative study of epidural anesthesia in dogs by weight or occipito-coccygeal distance ${ }^{1}$
}

\author{
Gisele Martins de Paula Leite', Luís Eugênio Franklin Augusto ${ }^{2 *}$, Vanessa Guedes Pereira ${ }^{3}$, \\ Adriano França Cunha ${ }^{2}$, Kelly Cristine de Sousa Pontes ${ }^{2}$, Jader Lúcio Pinheiro Santana ${ }^{2}$
}

10.1590/0034-737X201764010002

\begin{abstract}
The effects of volume on lumbosacral epidural block in dogs were evaluated using two different doses of $2 \%$ lidocaine. Ten adult dogs, without defined breed, were subjected to two different anesthetic protocols. In the first, the local anesthetic was calculated based on the body weight (GP), wherein $1.0 \mathrm{~mL}$ of local anesthetic was used for each 3.5 $\mathrm{kg}$; in the second protocol, the dose was stipulated according to the occipito-coccygeal (DG) distance with $1.5 \mathrm{~mL}$ of local anesthetic for every $10 \mathrm{~cm}$ of distance. The available time, recovery period, extent of block, and rectal temperature were measured. After the analysis of the results, it was possible to verify that there was an increase in the time in GD when compared with GP, due to the greater volume administered in that group. The recovery period remained similar in both groups, despite the use of different doses. Regarding the extent of blockade, there was an increase in GD in relation to GP due to the increase of the local anesthetic dose. On the other hand, the rectal temperature presented a difference between the groups, remaining lower and below the reference values for the species in GD compared with GP at all moments analyzed, possibly due to a sympathetic action triggered by the cranial extension of the epidural block. It could be concluded that when a longer time and a more cranial blockade of epidural anesthesia are desired, the anesthesia volume should be based on the occipito-coccygeal distance, however, observing the rectal temperature.
\end{abstract}

Key words: lidocaine; volume; timing; recovery time; rectal temperature.

\section{RESUMO}

\section{Estudo comparativo da anestesia epidural em cães por peso ou distância ocipto-coccígea}

Avaliaram-se os efeitos do volume no bloqueio epidural lombossacro em cães utilizando-se duas doses diferentes de lidocaína a $2 \%$. Foram utilizados dez cães adultos, SRD submetidos: No primeiro protocolo, o anestésico local foi calculado com base no peso corporal (GP) e no segundo protocolo a dose foi estipulada de acordo com a distância ocipto-coccígea (GD). Sendo os mesmos animais submetidos aos dois protocolos anestésicos, com intervalo de dez dias. Mensurou-se o tempo hábil, o período de recuperação, a extensão do bloqueio e a temperatura retal. Após a análise dos resultados foi possível constatar que houve acréscimo no tempo hábil em GD quando comparado a GP, devido ao maior volume administrado em tal grupo. O período de recuperação se manteve semelhante em ambos os grupos, apesar do uso de doses diferentes. Com relação à extensão do bloqueio, houve um aumento em GD quando comparado a GP devido ao aumento da dose de anestésico local. Já a temperatura retal apresentou diferença entre os grupos, mantendose menor e abaixo dos valores de referência para a espécie, em GD na comparação com GP em todos os momentos analisados possivelmente devido a uma ação simpática desencadeada pela extensão cranial do bloqueio epidural. Pode se concluir que quando se dejesa um maior tempo hábil e um bloqueio mais cranial de anestesia epidural, o volume da mesma deve-se basear na distância occipto-coccígeo, porém, cuidados com a temperatura retal devem ser tomados.

Palavras-chave: lidocaína; tempo hábil; tempo de recuperação; temperatura retal.

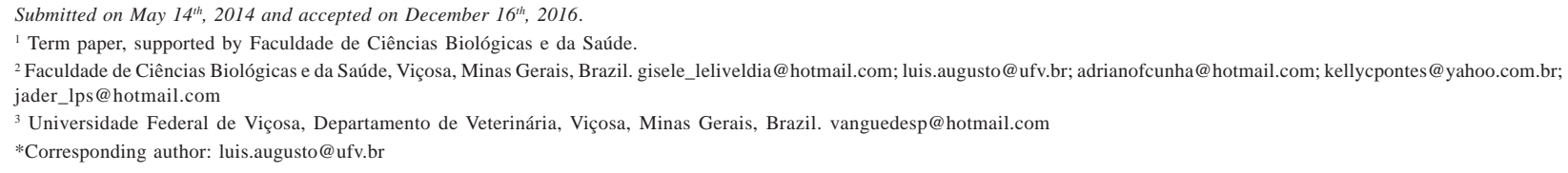




\section{INTRODUCTION}

Epidural anesthesia is a simple, safe, effective, and lowcost technique characterized by the administration of drugs with analgesic properties in the epidural space aiming at promoting anesthesia and analgesia (Otero, 2005; Skarda \& Tranquilli, 2007; Cassu et al., 2008; Tamanho et al., 2009).

The action of the drug, when applied by the epidural route, will depend on the volume administered, speed of application, diffusion through the intervertebral foramens and dura mater, concentration and liposolubility of the drug, and the length of the vertebral column (Otero, 2005; Skarda \& Tranquilli, 2007). Factors such as gestation, obesity, age, pressure within the epidural space, venous and lymphatic absorption, and rate of anesthetic elimination may also interfere with the drug progression after epidural application (Skarda \& Muir III, 1996).

According to Otero (2005), the cephalic progression of the block depends on the volume of the substance administered via the epidural. Hypothermia, due to sympathetic block, may occur within the first few minutes after drug application, especially if it is done rapidly (Otero, 2005; Skarda \& Tranquilli, 2007; Andrade, 2009; Santos et al., 2009).

There are two ways of calculating the dose of agents administered via the epidural route according to the desired effect (Skarda \& Tranquilli, 2007). The first one, by taking into account the body weight of the animal and the second is based on the extension of the vertebral column (Otero, 2005; Skarda \& Tranquilli, 2007; Santos, 2009). Thus, it is possible to adjust the dosage to the different patients, providing a satisfactory block in each situation, besides avoiding adverse effects (Torske \& Dyson, 2000; Egger \& Love, 2009).

When using the dose in $1.0 \mathrm{~mL}$ for each $4.5 \mathrm{~kg}$ of weight, analgesia and anesthesia are delivered to the first lumbar vertebra in the dog, blocking the perineum, pelvic limbs, and caudal abdomen (Campello et al., 1977; Jones 2001; Otero, 2005; Skarda \& Tranquilli, 2007; Andrade, 2009; Tamanho et al., 2009). Otero (2005) suggests the use of 1.5 $\mathrm{mL}$ for each $10 \mathrm{~cm}$ of occipito-coccygeal distance to promote a satisfactory cranial block to the 5th thoracic vertebra, without compromising the respiratory dynamics. According to the same author, the calculation according to the weight can generate dosage errors, leading to unsatisfactory block and poor analgesia. This may be due to the low connection between the extent and volume of epidural space and body weight, especially in dogs, due to the variety of breeds and sizes (Otero, 2005; Andrade, 2009).

Thus, the present study aims to compare the available time and recovery time, the extent of anesthetic block, and the rectal temperature of dogs subjected to epidural anesthesia, considering the volume of the anesthesia by occipito-coccygeal distance or body weight.

\section{MATERIAL AND METHODS}

The present study was approved by the ethics committee of the Faculdade de Ciências Biológicas e da Saúde FACISA/UNIVIÇOSA, number 13/2013-1. The animals from the kennel of the Faculdade de Ciências Biológicas e da Saúde FACISA/UNIVIÇOSA and from owners, who voluntarily gave their animals, were selected based on weight and previous clinical examination.

Ten healthy adult dogs of both genders and without defined breed, weighing between 13.2 and $22.0 \mathrm{~kg}(17.4 \pm$ 3.0) were used. Before the anesthetic protocol, the animals were subjected to food fasting for $12 \mathrm{~h}$ and to water fasting for $6 \mathrm{~h}$. All animals had the weight and the distance between the occipital protuberance and the first coccygeal vertebra measured previously.

We performed the catheterization of the cephalic vein, by which fluid therapy with $\mathrm{NaCl} 0.9 \%(250 \mathrm{ml}$ of $\mathrm{NaCl}$ injectable electrolyte solution - Sanobiol LTDA, Pouso Alegre - MG) at $10 \mathrm{~mL} / \mathrm{kg} / \mathrm{h}$ was administered during all the experimental moments. The anesthetic induction was performed with $8 \mathrm{mg} / \mathrm{kg} / \mathrm{IV}$ propofol (Provive, Propofol 10\%, Meizler BIOPHARMA S/A Chacharwadi - Vasana, Ahmedabd-382 213, India) until the animals reached adequate surgical anesthetic plan, based on criteria of clinical judgment (rotated ocular bulb, absent palpebral reflex, relaxed jaw, and absence of spontaneous muscular movements in response to the stimuli caused by the penetration of the needle into the lumbosacral space). After anesthetic induction, the animals were randomly divided into two groups of 10 animals each; in this way, each animal was anesthetized in two different moments; first, belonging to one group and in a second moment, belonging to the other group. The interval between participation in each group was 10 days.

To perform the epidural, the animals were placed in sternal decumbency with the limbs drawn cranially. The administration of lidocaine $2 \%$ (20 mL lidocaine hydrochloride, $20 \mathrm{mg} / \mathrm{mL}$ - Hypofarma, Ribeirão das $\mathrm{Ne}$ ves - MG) occurred in an average time of $60 \mathrm{~s}$. The animals were maintained in sternal decumbency until the end of the evaluations.

The ten animals were divided into two groups that received two distinct anesthetic protocols, in an average interval of ten days. In the first group, the animals were subjected to epidural anesthesia by calculating the total volume of the anesthetic according to weight, as follows: $1 \mathrm{~mL}$ of lidocaine $2 \%$ without vasoconstrictor for each 3.5 $\mathrm{kg}$ (GP). In the second group, the total anesthetic dose was calculated from the occipito-coccygeal distance, as 
follows: $1.5 \mathrm{~mL}$ of lidocaine $2 \%$ for each $10 \mathrm{~cm}$ occipitococcygeal (GD). When calculating the dose based on the occipito-coccygeal distance, there was an increase of approximately $50 \%$ in the volume in relation to the volume obtained from the calculation by weight.

The anesthetic available period, the recovery period, the extent of the block, and the rectal temperature were analyzed. The available time comprised the interval, in seconds, between the administration of lidocaine $2 \%$ and the appearance of the first voluntary movements of the pelvic limbs. The recovery time, in seconds, was measured and corresponded to the interval between the end of the available time until the complete ambulation of the animal.

The extension of the epidural block was measured by pinching the skin using an Allis clamp, pressed until the first rack, to analyze the pain sensation. The stimulus was applied in the dorsal region, starting in the lumbosacral region and following cranially until the animal responded to the nociceptive stimulus. When they presented a painful response, the animals emitted sounds of discomfort, showed resistance to the stimulus, or turned their heads towards the stimulated site. The extent of the block was measured using a tape measure (Misura Per Sarti C\&C - São Paulo, SP), in centimeter scale, from the region of the anesthetic application to the place in which the animals showed sensitivity. The rectal temperature was measured with a digital clinical thermometer (Axilar TS-101: Techline). The extent of the block and temperature were measured in six preestablished periods, in which the moment 0 corresponded immediately before performing the epidural anesthesia; moment 1, 15 min after epidural anesthesia; moment 2, 15 min after moment 1 ; moment 3, 30 min after moment 1 ; moment 4, 45 min after moment 1; moment 5, 60 min after moment 1; and moment 6, 75 min after moment 1 .

Data were subjected to the Shapiro-Wilk test for normality of the variables and to the Breusch-Pagan/CookWeisberg test for homoscedasticity. For comparison of the means, the results referring to the available time and recovery time were subjected to Student's t-test, with equal variances between treatments. The results concerning the rectal temperature were subjected to the analysis of variance and covariance (Two-way Anova), to be compared by the Tukey test. The results regarding the stimulus distance were subjected to the Wilcoxon and Friedman non-parametric test. The analyzes were performed using software Stata 12.0 (StataCorp LP, Texas, USA), at the $5 \%$ level of significance.

\section{RESULTS AND DISCUSSION}

There was an increase in available time, with difference of $37.4 \%$ in GD compared with GP(Figure 1). According to
Jones (2001) and Skarda \& Tranquilli (2007), the duration of epidural anesthesia is related to the drug chosen, as well as to the range reached and whether or not adrenaline is used. Also, according to Otero (2005), the effect of epidural depends on the dose and volume administered, the liposolubility, and the protein binding of the drug. Therefore, it is possible to rule out the drug-related aspects and the particularities of the patient, since all the animals went through the two groups and received the same drug (lidocaine 2\%). It is suggested that the increase in available time observed in GD is due to the higher volume of drug administered, agreeing with Freire (2008) that, when using different volumes of bupivacaine, a larger number of blocked segments was obtained with the application of larger volumes if compared with the smaller ones. This was already expected, since administration of higher amounts of drug triggers greater action.

The duration of block found in this study (Figure 1) was higher than the values described in the literature for the use of lidocaine $2 \%$ without a vasoconstrictor via the epidural route, between 3600 and 5400 seconds (Otero, 2005).

Regarding the recovery time, no significant differences were observed between GP and GD, although the gain of $5.68 \%$ of this variable in GD was observed in relation to GP (Figure 2). In a study conducted by Freire (2008), it was observed that the regression of the sensory block occurs first, when compared with the motor block, when smaller volumes of anesthetic are used via the epidural route. According to the same author, this is due to the effect of the concentration that the anesthetic reaches within the epidural space, because, when injecting a larger volume of anesthetic, a block of the more cranial segments is obtained. However, the concentration achieved would be lower and, therefore, the motor block would not be as effective, which in turn occurs with the administration of smaller volumes, since these do not disperse as much, being concentrated in a certain region. Therefore, the absence of difference in recovery time between the two groups can be attributed to the more effective motor block promoted by the lower volume of lidocaine in GP, generating an inefficient ambulation for a longer time.

In the comparison between the groups over time, the increase in the extent of the sensory block, with statistical difference, occurred from moment 2 and remained until moment 6 , being higher in GD throughout the interval (Figure 3). When analyzing the variation among the moments of the groups, it was observed that the most cranial dispersion of lidocaine $2 \%$ occurred in moment 3 and from this, the block began to regress until moment 6 , without, however, returning to the value found in moment 0 . The distribution of the drug by the epidural space is influenced by the dose and volume administered, concentration and liposolubility of the drug, rate of application, severity, age, extension of the spine, and 
clinical status of the patient (Torske \& Dyson, 2000; Otero, 2005). According to Cassu et al. (2010), it is possible to obtain a more cranial anesthetic block using higher volumes in the epidural space. Considering that all animals went through the two assessment groups, receiving lidocaine $2 \%$ at a similar rate of application (about one minute) and were kept in the same position, the most cranial progression of GD block can be attributed to higher volume administered in that group. In addition, the decrease in block, with statistical difference, from moment 4 in GP and moment 5 in GD (Figure 3), indicates the return of the block. From these moments, the lidocaine 2\% concentration within the epidural space becomes insufficient to promote the block of the most cranial nervous roots, corroborating the results found by Freire (2008).
Regarding the rectal temperature between the groups over time, there was a difference in all the analyzed moments, with smaller values observed in the GD than in GP (Figure 4). After moment 2, the temperature values observed in GD (Figure 4) were below the reference levels for the species, which, according to Feitosa (2008), should be maintained between $37.5{ }^{\circ} \mathrm{C}$ and $39.2{ }^{\circ} \mathrm{C}$. However, in the comparisons among the moments analyzed for each group, there was a reduction of the rectal temperature with significant difference after moment 0 in both groups (Figure 4). According to Silva et al. (2008) and Jacobina (2009), the cranial progression of local anesthetic promotes sympathetic block, resulting in vasodilation of the arterioles and subsequent

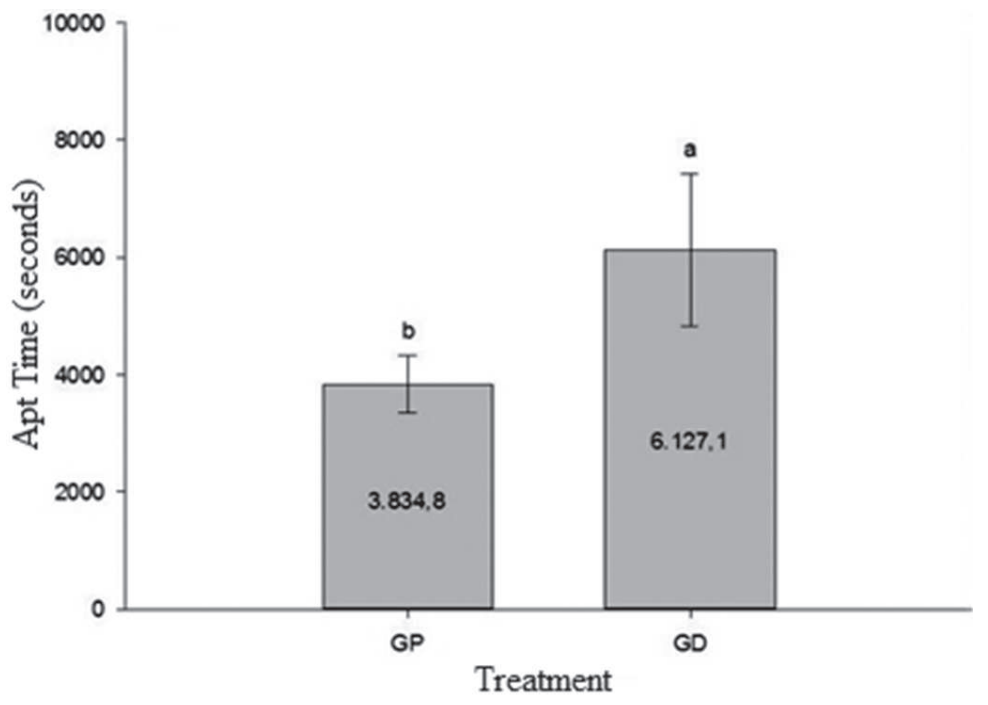

Figure 1: Values of the available time in seconds (mean \pm standard error) measured in dogs subjected to GP and GD treatments. Means between columns with the same letter do not differ by the Student $t$ test at $p<0.05$.

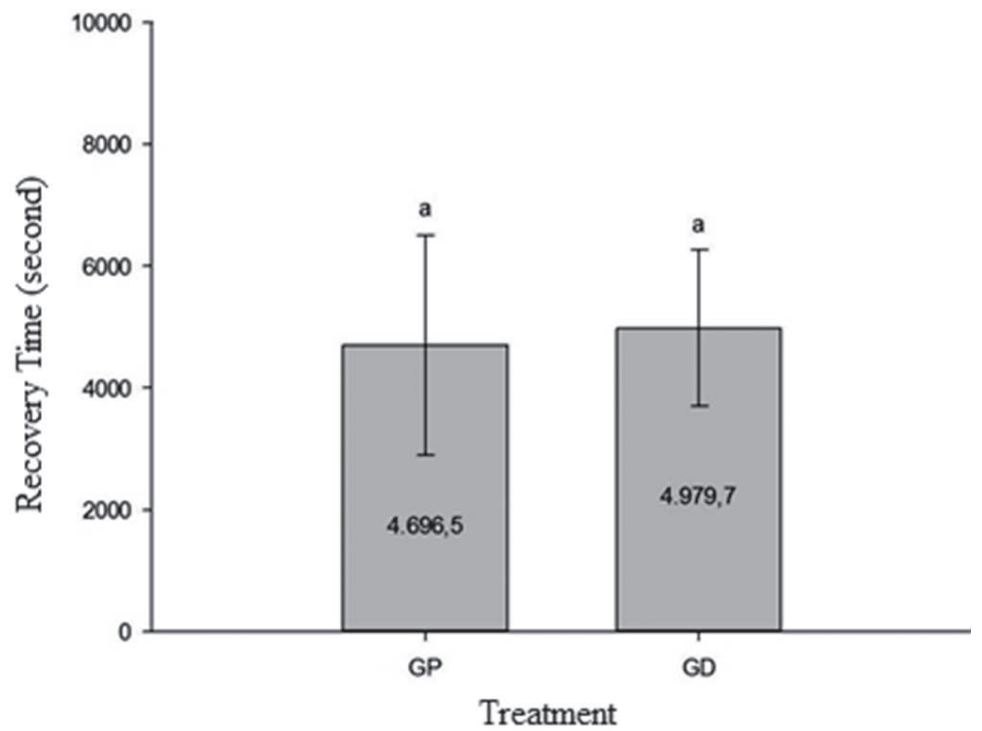

Figure 2: Recovery period values in seconds (mean \pm standard error) measured in dogs subjected to GP and GD treatments. Means between columns with the same letter do not differ by the Student $t$ test $p<0.05$. 


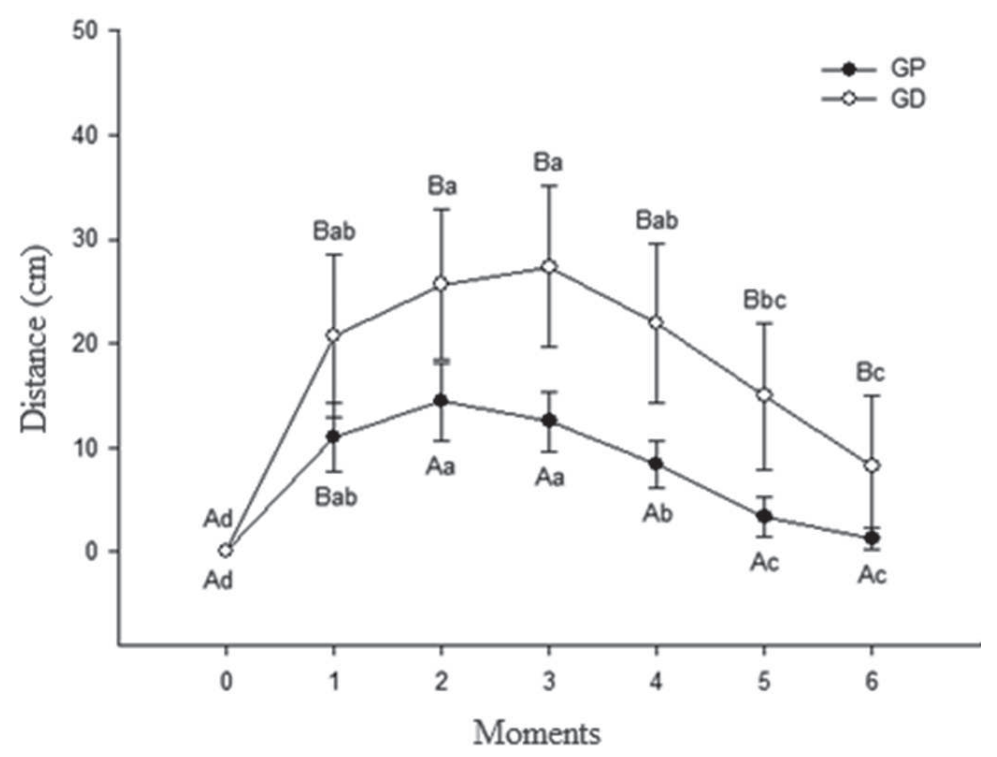

Means followed by different capital letters between the lines differ significantly by the Wilcoxon test at $\mathrm{p}<0.05$. Means followed by different lowercase letters on the same line differ significantly by the Fridman test at $\mathrm{p}<0.05$.

Figure 3: Values of the epidural block extension in centimeters (mean \pm standard error) measured in dogs subjected to GP and GD treatments at different moments of anesthesia.

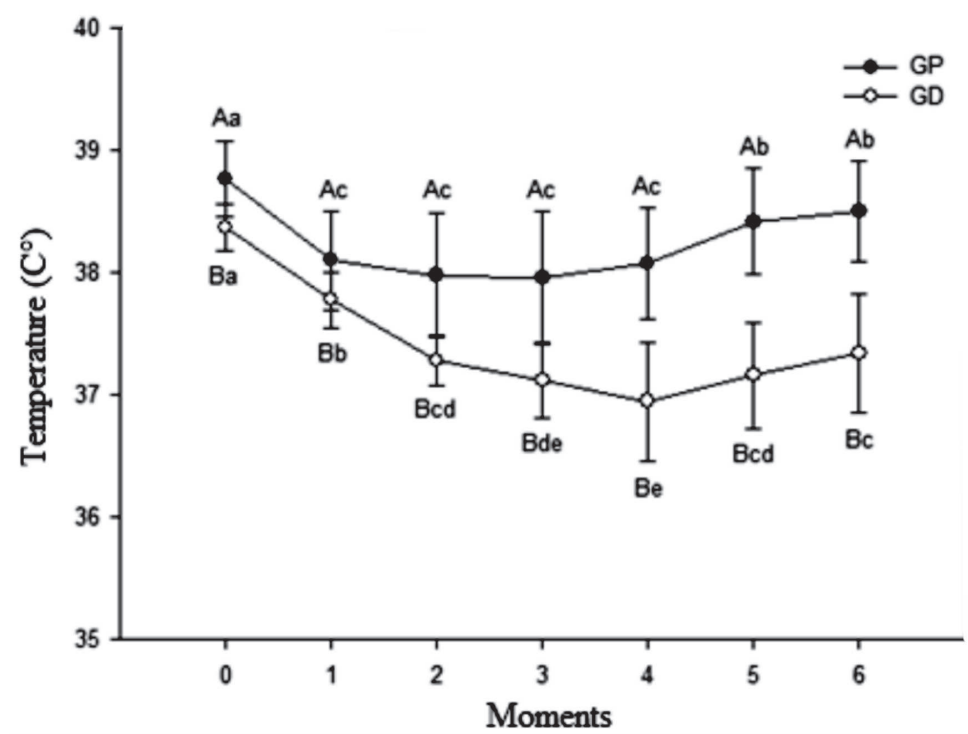

Figure 4: Values of rectal temperature in ${ }^{\circ} \mathrm{C}$ (mean \pm standard error) measured in dogs submitted to GP and GD treatments at different times of anesthesia.

Means followed by different capital letters between the lines differ significantly by the Wilcoxon test at $p<0.05$. Means followed by different lowercase letters on the same line differ significantly by the Fridman test at $p<0.05$.

hypothermia. According to Ishiy (2001) Skarda \& Tranquilli (2007), Cassu et al. (2008), and Tamanho et al. (2009), the epidural anesthesia leads to redistribution of heat through the body and to interference in central and peripheral thermoregulation, inducing the occurrence of hypothermia. In addition, induction with propofol causes hypotension resulting from arterial and venous vasodilation, which potentiates the redistribution of body heat (Branson, 2013). Thus, it is possible to attribute the lower values of the rectal temperature found in GD to the more cranial extension of the block. Although the rectal temperature increased again from moment 5 (Figure 4), it did not return to the values found in moment 0 . The decrease in rectal temperature, especially in GD, suggests that, when performing epidural anesthesia using the dose calculated by the occipito-coccygeal distance, caution should be taken with debilitated patients, in which thermoregulation is impaired. 


\section{CONCLUSION}

When a longer time and a more cranial block of epidural anesthesia are desired, the anesthesia volume should be based on the occipito-coccygeal distance; however, care with the rectal temperature must be taken.

\section{REFERENCES}

Andrade GR (2009) Anestesia epidural em cães: revisão de literatura. Monografia. Universidade Federal Rural do Semi-Árido, Mossoró. 40p.

Branson KR (2013) Anestesia Injetável e Técnicas Alternativas. In: Thurmon JC, Kurt AG \& Tranquilli WJ (Eds.) Lumb \& Jones - Veterinary Anesthesia and Analgesia. Iowa, Blackwell Publishing. p.767-779.

Campello RAV, Petrucci LAC, Araujo FC \& Wolle CA (1977) Observações sobre o emprego da bupivacaína na anestesia epidural em cães. Ciência Rural, 7:167-171.

Cassu RN, Stevanin H, Kanashiro C, Menezes LMB \& Laposy CB (2008) Anestesia epidural com lidocaína isolada e associada ao fentanil para realização de ovariossalpingohisterectomia em cadelas. Arquivo Brasileiro de Medicina Veterinária e Zootecnia, 60:825-831.

Cassu RN, Melchert A, Machado GM \& Meirelles CC (2010) Anestesia peridural com lidocaína isolada ou associada à clonidina: efeito cardiorrespiratório e analgésico em cães. Ciência Rural, 40:2129-2134.

Egger CM \& Love L (2009) Local and regional anesthesia techniques - Part 1: Overview and five simple techniques. Veterinary Medicine. Disponível em: <http://veterinarymedicine.dvm360.com/local-and-regional-anesthesia-techniquespart-1-overview-and-five-simple-techniques?rel=canonical>. Acessado em: 20 de dezembro de 2014

Feitosa FL (2008) Semiologia Veterinária: a arte do diagnóstico. São Paulo, Rocca. 784p.

Freire CD (2008) Avaliação da dispersão da bupivacaína na anestesia peridural em cães. Tese de Doutorado. Universidade de São Paulo, São Paulo. 84p.

Jacobina GC (2009) Uso da ropivacaína ou levobupivacína na anestesia epidural toraco-lombar em cães. Dissertação de Mestrado. Universidade Federal de Uberlândia, Uberaba. 84p.

Jones RS (2001) Epidural analgesia in the dog and cat. The Veterinary Journal, 161:123-131.

Ishiy MH (2001) Uso da lidocaína isolada ou associada à quetamina ou ao butorfanol, em anestesia epidural em cães: avaliação cardiorrespiratória e analgésica. Dissertação de Mestrado. Faculdade de Medicina de Botucatu, Botucatu. 104p.

Otero PE (2005) Administração epidural e espinhal de analgésicos: Dor avaliação e tratamento e pequenos animais. São Caetano do Sul, Interbook. 393p.

Santos GJ, Piraja GV, Dias LGG \& Pereira DM (2009) Anestesia epidural em pequenos animais. Revista Científica Eletrônica de Medicina Veterinária, 12:45-50.

Skarda RR \& Muir III WW (1996) Analgesic hemodinamic and respiratory efeccts of caudal epidurally administered xylazine hydrochloride in mares. American Journal of Veterinary Research, 57:93-200.

Skarda RT \& Tranquilli WJ (2007) Local and Regional Anesthetic and Analgesic Techniques: Dogs. In: Grimm K, Thurmon J \& Tranquilli WJ (Eds.) Lumb \& Jones - Veterinary Anesthesia and Analgesia. Iowa, Blackwell Publishing. p.561-594.
Silva BM, Matsubara LM, Albuquerque VB, Maia CAA \& Oliva VNLS (2008) Ropivacaína isolada e associada ao fentanil ou ao tramadol administrados pela via peridural em cães. Ciência Rural, 38:2197-2202.

Tamanho RB, Oleskovicz N, Moraes AN, Flôres FN, Dallabrida AL, Regalin D, Carneiro R, Pacheco AD \& Rosa AC (2009) Anestesia epidural cranial com lidocaína e morfina para campanhas de castração em cães. Ciência Rural, 40:155-122.

Torske KE \& Dyson DH (2000) Epidural analgesia and anesthesia. Veterinary Clinics of North America: Small Animal Practice, 30:859-875. 